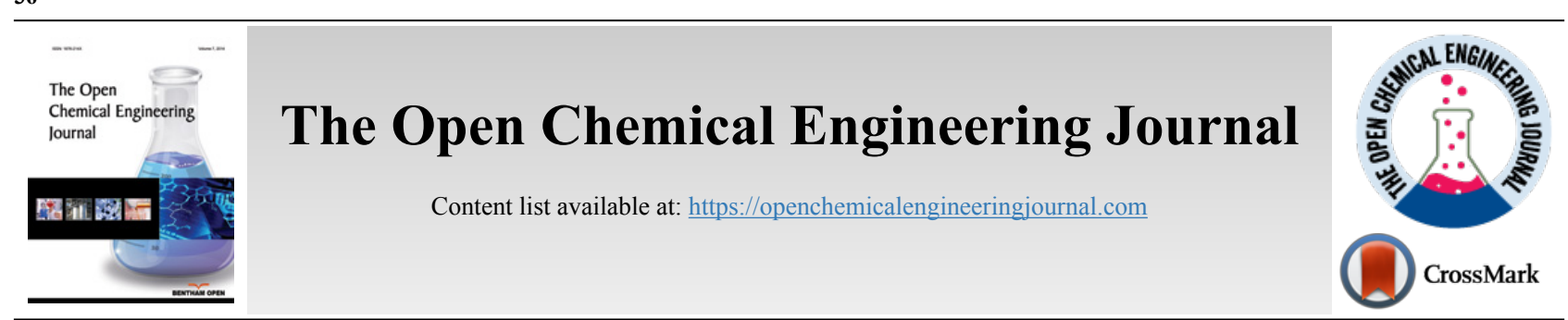

RESEARCH ARTICLE

\title{
Current and Future Global Lithium Production Till 2025
}

\author{
Daniel Calisaya-Azpilcueta $^{1, *}(\mathbb{D})$, Sebastián Herrera-Leon ${ }^{2,3}$ and Luis A. Cisternas ${ }^{1, *}$ \\ ${ }^{I}$ Departamento de Ingeniería Química y Procesos de Minerales, Universidad de Antofagasta, Antofagasta, Chile \\ ${ }^{2}$ School of Engineering Science, LUT University, P.O. Box 20, FI-53851 Lappeenranta, Finland \\ ${ }^{3}$ Departamento de Ingeniería Química, Universidad Católica del Norte, Avenida Angamos 0610, Antofagasta, Chile.
}

\begin{abstract}
:
Background:

The production of lithium is growing continuously, and ensuring its stable supply is crucial for the growth of global economy. Therefore, to avoid a potential supply risk, it is necessary to determine the requirements for the implementation of current and planned lithium mining projects in order to meet the forecasted demand of lithium.

Objective:

In this paper, the capability of global lithium production to meet the uncertain, high or low level, demand by 2025 , is analyzed.

Methods:

The global lithium supply is simulated considering three alternatives: no new projects in the portfolio, committed projects, and uncommitted projects. Two scenarios for estimating the growth rate of lithium production in the future are analyzed: a regular growth rate and a growth rate assuming the use in full capacity of lithium production by major suppliers.
\end{abstract}

Results:

The results show that the total capacity of production covers the low-level demand. However, it is not enough to cover the high-level demand for lithium. Therefore, new projects are necessary. On the other hand, results considering all the possible projects show that the demand is exceeded, which suggests that intermediate scenarios could cover the demand by $100 \%$.

Conclusion:

It is expected that a low-carbon economy may be projected soon, and assuming the high-level demand of lithium, then a combination of committed projects and uncommitted projects should be considered.

Keywords: Lithium, Supply, Demand, Uncertainty, Future scenarios, low-carbon economy.

\begin{tabular}{|l|l|l|l}
\hline Article History & Received: December 29, 2019 & Revised: April 14, 2020 & Accepted: April 20, 2020
\end{tabular}

\section{INTRODUCTION}

In recent years, concerns about critical materials have been increasing [1]. The criticality of a given material is evaluated with the level of supply risk and the impact that this potential risk would have on the whole system in a determined timeframe [2]. These supply risks would have a significant

\footnotetext{
"Address correspondence to these author at the Departamento de Ingeniería Química y Procesos de Minerales, Universidad de Antofagasta, Antofagasta, Chile,E-mails: Daniel.calisaya@uantof.cl and luis.cisternas@uantof.cl
}

impact on the operation of companies and the maintenance of the current standards of societies. Lithium is considered a critical material because it plays an essential role in the development of a low-carbon economy [3]. However, lithium compounds are also used in systems, such as military, communication, and especially in the production of several industrial applications, such as ceramics and glasses, lubricants and greases, pharmaceutical products, and aluminum products, among others [4]. A general scheme of the lithium processing stages is shown in Fig. (1), and each stage is described in more detail below. 


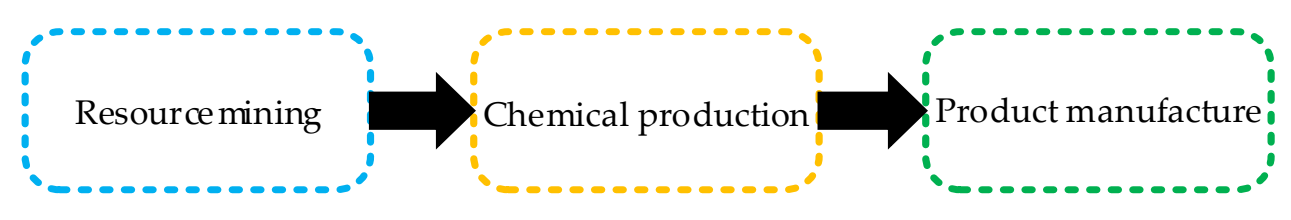

Fig. (1). Lithium processing stages (adapted from [5]).

In the resource mining stage, there are three types of lithium sources - brines, ores, and clays. However, most of the lithium resources are obtained from brines and ores deposits [6]. According to the United States Geological Survey (USGS) report in 2017, the total lithium resources are 53 million tones, and the total reserves are 16 million tonnes [7]. The resources are defined as the naturally occurring solid, liquid, or gaseous material on the earth's crust, and reserves are commodities that could be economically extracted or produced [8]. The most important sources of brines are in Chile, Argentina, and Bolivia; whereas, the ores deposits are mainly located in Australia and China. It is also possible to find lithium deposits in Europe and other countries, such as Brazil, Canada, Portugal, the US, and Zimbabwe. However, these deposits only represent roughly $3.5 \%$ of the resources worldwide [4].

The chemical production stage represents the production of lithium compounds and their derivatives from the sources mentioned above. The most common lithium compounds are lithium carbonate, lithium hydroxide, and lithium chloride [5], [9]. Besides, lithium concentrate plays a fundamental role in this stage. There are two types of lithium concentrate - the technical-grade concentrate and the chemical-grade concentrate. The technical-grade lithium concentrate is mainly used for the manufacturing of glasses and ceramics, whereas the chemical-grade lithium concentrate is used in chemical plants to produce lithium compounds [10]. Lithium derivatives are considered as chemical products fabricated from lithium compounds [11]. The main lithium derivatives are butyl lithium and lithium metal. It is worth mentioning that in the world, there are only four countries that ensure more than $90 \%$ of global chemical production: Chile, Australia, Argentina, and China [12].

In the product manufacturing stage, lithium compounds and derivatives, as well as lithium concentrate, are used to make a wide range of goods. The main applications of lithium worldwide are - lithium-ion batteries, ceramics and glasses, lubricants and greases, continuous casting molds powders, refrigerants, polymers, and aluminum alloys [4]. Currently, lithium-ion batteries are the main application of lithium, whereas ceramics and glasses are the second ones, sharing respectively $35 \%$ and $32 \%$ of the global lithium market [4]. There are also some goods with a low share in the global lithium market, e.g., pharmaceuticals, cement additives, organic synthesis products, flavor and fragrances, dyes and pigments, organic intermediates, as well as catalysts and fireworks $[4,13]$.

Because lithium cannot be substituted in most applications, therefore, its supply risks are influenced by demand increase. $8-11 \%$ annual growth of lithium demand is anticipated [4]. For example, lithium use in the battery industry increased from zero to $80 \%$ of the market share between 1991 and 2012 . The leading consumer of lithium is China, with $35 \%$ of the total world consumption, followed by Europe, Japan, the Republic of Korea, and North America with 24\%, 12\%, 10\%, and 9\% of the world consumption, respectively [14]. Furthermore, the demand for lithium will have a significant increase in the forthcoming years, mainly due to the fast-increasing demand for lithium-ion batteries [12 - 14]. Consequently, in the coming years, this phenomenon will result in several challenges to the suppliers. Hence, the determination of the capacity of each supplier is of primordial importance to evaluate if it will be possible to supply the increasing demand in the coming future [15].

The production of lithium has continuously grown [16]. However, as the demand is dynamically increasing, it does not mean that the future supply would be satisfied [4]. Therefore, to avoid a potential supply risk, it is important to determine the requirements for the implementation of current and planned lithium mining projects to satisfy the forecasted demand of lithium. The main objective of this paper is to evaluate the capability of suppliers to meet the lithium demand by the output of the current mining projects, as well as committed and uncommitted ones. The research is focused on the assessment of the production capacity of the top lithium suppliers - Chile, China, Australia, and Argentina.

\section{METHODOLOGY}

The methodology used in this article is based on three steps: data collection, system dynamics modeling, and scenario building. The data collection is performed to determine the global lithium supply from 1981 to 2015 and the estimated lithium demand in the years 2015 to 2025 . The system dynamics model is designed to analyze the dynamic behavior of stocks and flows in the supply chain of lithium. Scenario building is used to estimate the lithium supply between 2015 and 2025 considering different growth rates in the production capacity of the world suppliers. A detailed description of each step of the methodology is presented below.

\subsection{Data Collection}

The collected data covers the period from 1981 to 2025 (Appendix, Table A1. The data is mainly from institutional reports, as shown in Fig. (2). In the resource mining stage, the historical data for the countries producing lithium are obtained from USGS for years 1981-2015 [17 - 39]. In the chemical production stage, the report of the Center for Energy and Economics provides information corresponding to the conversion from the resource mining stage to the product 
manufacturing stage in 2015 [40]. In the product manufacturing stage, two databases are used to show the estimated demand for lithium quantitatively until 2025; reports are provided by Macquarie University and Deutsche Bank [41].

The estimation of Deutsche Bank considers that the increase in battery demand is a driving force of the future rising demand for lithium. This report assumes that in the future, mobility will be based on electric vehicles; hence, the demand for lithium will increase proportionally to the demand for those means of transportation. Deutsche Bank estimates that the share of electric vehicles in the global lithium market demand will be more than $50 \%$ in 2025 . When considering fuel efficiency versus $\mathrm{CO}_{2}$ regulations in the U.S. and Europe, the fundamental assumption made by Deutsche Bank for the assessment of battery demand is the statement that electric vehicles should reach cost parity with internal combustion cars by the early 2020s and with power diesel trains within the next five years. Therefore, the Deutsche Bank estimation of required lithium in the future is considered as high-level demand in this study. Deutsche Bank data include the application of lithium in electric vehicles, energy storage, traditional batteries, e-bikes, glass and ceramics, greases, air treatment, polymers, medicaments, primary batteries, aluminum, and casting powders.

On the other hand, the estimation of demand by Macquarie University indicates that the main driver of lithium demand is electric vehicle penetration in the global market as well as some other factors. Macquarie University assumes that increasing passenger vehicle battery size and steady growth in electric bus and truck production in China are also key factors. Their estimation is based on the growth of the companies that will produce these vehicles, specifically Tesla and China vehicle manufacturers. They consider that lithium has the most significant growth among mined commodities, but still, their estimations are below the Deutsche Bank assessment. Therefore, in this article, Macquarie University's estimation of required lithium in the future is considered as low-level demand. The applications considered in this study are hybrid and plug-in electric cars, energy storage systems, two wheels' electric vehicles, ceramic and glass, lubricant greases, air conditioning, polymers, medicaments, other batteries, aluminum, and continuous casting.

\subsection{System Dynamics Model}

The system dynamics method is used in this study for two reasons. First, we need to quantify the changes in time of various lithium streams, from mining to manufacturing. Second, we need to analyze the potential capacity of main national suppliers to meet the lithium demand in the specified timeframe [42, 43].

All variables and parameters nomenclature are given in Appendix, Table A1. Based on the system dynamics method, we developed a stock and flow model of the lithium flows. The model consists of three major segments, as shown in Fig. (1). The segments are marked by three colors: blue - resource mining stage, yellow - chemical production, green - product manufacturing as shown in Fig. (3). In the first stage, resource mining, the production in Chile, Argentina, Australia, China, Canada, Brazil, Portugal, Zimbabwe, Namibia, Russia, and the United States, is taken into account. In the second stage, chemical production corresponds to the processes of making butyl lithium, lithium metal, lithium chloride, lithium carbonate, lithium hydroxide, and lithium concentrate. Finally, the third stage includes products containing lithium, such as polymers, batteries, air treatment equipment, aluminum alloys, metal casting powders, ceramics and glasses, lubricant greases and others.

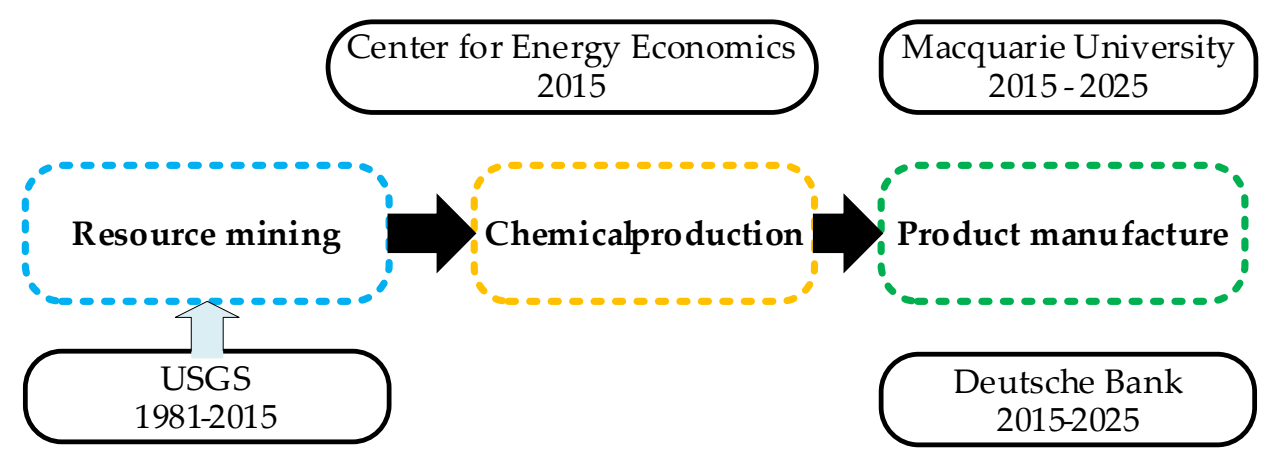

Fig. (2). Data sources through the processing stages. 


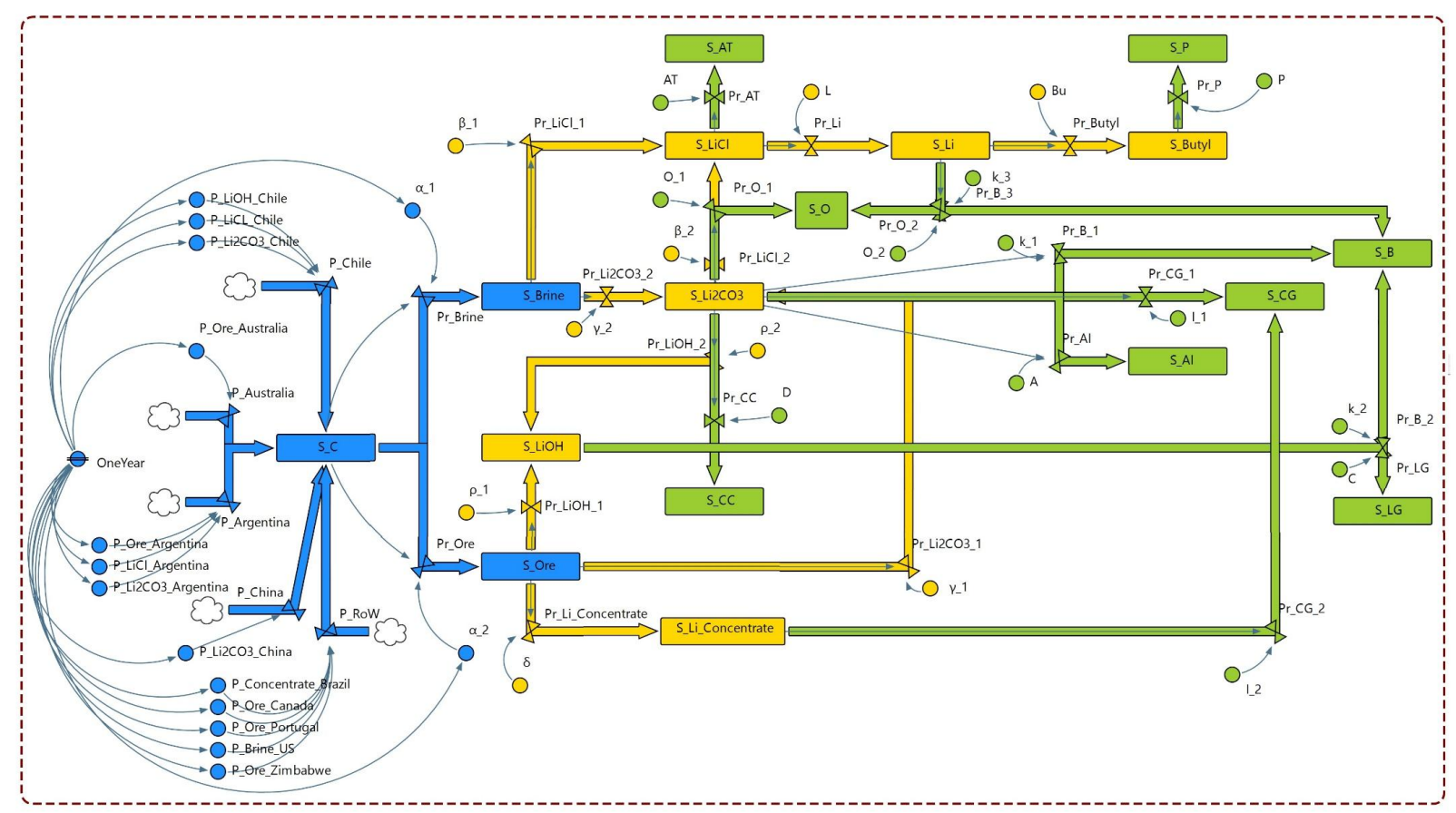

Fig. (3). Stock and flow diagram of the lithium processing stages.

It is important to note that every variable in the system dynamics model is calculated at each time step. For example, in this simulation, we consider the time step equal to one year as the input data are based on yearly reports. As explained in the previous section, data are collected for years $1981-2025$. The dynamic behavior of the lithium processing stages is simulated by a set of mathematical equations, which is provided in detail in Appendix, Table A1.

The stock equation is given by Forrester [43] as:

$$
\operatorname{Stock}(t)=\int_{t_{0}}^{t}[\operatorname{Inflow}(t)-\text { Outflow }(t)] d t+\operatorname{Stock}\left(t_{0}\right)
$$

Where, $t$ is the initial year and $t$ is the final year considered; Stock $(t)$ is a mass accumulated in the system at the time $t$ of the period 1980-2025 due to influx Inflow $(t)$ and loss Outflow(t).

$$
\operatorname{Inflow}(t)=f(\operatorname{Stock}(t), V(t), P) ; \text { Outflow }(t)=f(\operatorname{Stock}(t), V(t), P)
$$

Where, $V(t)$ is an auxiliary variable in time $t$. For example, in the lithium model, the brine process as flow depends on the amount of extracted brine and the stock of the global supply of lithium. $P$ represents input parameters, such as the concentration of production and coefficient of processing (all input parameters are given in Appendix, Tables A2, A3).

The initial flows of the model occur in the mining stage. For example, the mathematical representation of the global supply of lithium $S_{G}(t)$ is given as follows:

$$
\begin{aligned}
& S_{G}(t)=\int_{t 0}^{t}\left(P_{\text {Chile }}(t)+P_{\text {Australia }}(t)+P_{\text {Argentina }}(t)+P_{\text {China }}(t)\right. \\
& \left.+P_{\text {Rest of World }}(t)-P r_{\text {Brine }}(t)-P r_{\text {Ore }}(t)\right) d t+S_{G}\left(t_{0}\right)
\end{aligned}
$$

Where the primary production of lithium by Chile $\left(P_{\text {Chile }}(t)\right)$, Australia $\left(P_{\text {Australia }}(t)\right)$, Argentina $\left(P_{\text {Argentina }}(t)\right)$, China $\left(P_{\text {China }}(t)\right)$ and other countries including Brazil, Canada, Portugal, the US, and Zimbabwe $\left(P_{\text {Rest of World }}(t)\right)$ is considered. Two processes including brine processing $\left(\operatorname{Pr}_{\text {Brine }}(t)\right)$ and ore processing $\left(P r_{\text {Ore }}(t)\right)$ are assumed as the main chemical processes in this step. $S_{G}\left(t_{O}\right)$ is the initial stock of the global supply of lithium.

\subsection{Scenario Building}

This study focuses on the production capacity of the top lithium suppliers (Chile, Australia, Argentina, and China) as these suppliers affect the system considerably. One of the main criteria for estimating the future lithium supply is the analysis of different types of projects that will increase global lithium production. The lithium production projects could be classified as no New Project (NP), Committed Projects (CP), and Uncommitted Projects (UCP). The projects from CP and UCP are considered from the Canaccord report [13].

Two scenarios for the future growth rate of lithium production have been considered: regular growth rate (Reg scenario) and full capacity growth rate (FC scenario). Both are related to the increase in capacity. The regular growth scenario considers the increase in production until now, and will continue with the same annual growth rate, based on historical data. In this case, the capacity depends on the production growth rate. The full capacity growth scenario expects that the capacity of production of each country will reach $100 \%$ in 2025, unlike the previous scenario, in which the production growth rate depends on the production capacity.

These scenarios are proposed to analyze the ratio of 
lithium supply and demand in three phases of its processing: mining, chemical production, product manufacturing.

The scenarios are based on the Compound Annual Growth Rate (CAGR) to assess the current and future production of lithium. Results are compared with the low and high level of future lithium demand until 2025.

In literature, the CAGR measure has been used to quantify the growth of the demand for electric vehicles [44]. Equation 4 represents the equation of CAGR [45], in which the variables used are the lithium production amount in two different years as the initial value $P_{i v}$ and final value $P_{f v} ; N$ is the period (years) between those two produced amounts.

$$
C A G R=\left(\frac{P_{f v}}{P_{i v}}\right)^{\frac{1}{N}}-1
$$

In scenario Reg, CAGR is calculated for each country for the ten-year period 2005-2015. In 2015, none of the countries has been using $100 \%$ of its production capacity. The CAGR calculated for the period 2005-2015 is used to estimate the supply for 2015-2025. This estimation is given by Equation 5 [45].

$$
P_{f v}^{\prime}=P_{i v}^{\prime} *(1+C A G R)^{N}
$$

Where, the future lithium production value is $P_{f}^{\prime}$; initial lithium production value is $P_{i v}^{\prime} ; C A G R$ is the compound annual growth rate; $N$ is the given period (years).

In scenario FC, CAGR depends on the maximum capacity of production of each country. In this scenario, the calculated CAGR assumes that all countries will reach $100 \%$ production capacity. After deriving the CAGR, the estimation of production is determined year by year. Since not all countries have the same lithium production growth year by year, the CAGR is calculated for each country separately, and next, an estimation for each country is completed. The estimation of the global lithium supply is given by the summation of lithium production in all countries.

Table 1. Percentage of the maximum capacity of production for each country in 2015 [13].

\begin{tabular}{|c|c|}
\hline Country & Capacity of Production in 2015 (\%) \\
\hline Argentina & 51 \\
\hline Australia & 65 \\
\hline Chile & 62 \\
\hline China & 20 \\
\hline
\end{tabular}

The production capacity is an essential part of the analyzed scenarios. Table 1 shows the percentage of the maximum production capacity used by each country in 2015 , according to the Canaccord report [13].

\section{RESULTS AND DISCUSSION}

According to the databases used in this study, as shown in Fig. (1), the flows between resource mining, chemical production, and product manufacture are calculated as material flow. We present in Fig. (4) the material flow between lithium processing stages using the production data of the major producers in 2015, according to the report of the Center of Energy Economics [46].

In Fig. (4), the quantity of material at each flow is proportional to the thickness of the arrow. The largest arrows in the figure are the flows of lithium brine and lithium concentrate from the resource mining stage to the chemical production stage, as well as the flows of lithium carbonate and lithium concentrate from chemical production to product manufacturing stage. All the lithium flows shown in Fig. (4) are measured in thousands of tonnes.

The diagram in Fig. (4) supports the finding of the Center of Energy Economics database, which points out that the essential elements in the chemical production stage are carbonate and concentrate as well as the most important elements in the product manufacturing stage are batteries, ceramic and glasses.

Considering the USGS database and the reports of Macquarie University and Deutsche Bank, Fig. (5) presents the historical global supply of lithium as well as the low and highlevel demand for it. The high-level demand will reach around 493 thousand tonnes of LCE by 2025 with a CAGR of $11 \%$, whereas the low-level demand for lithium will reach ca. 393 thousand tonnes of LCE by 2025 with a CAGR of $9 \%$.

Table 2 gives the calculated CAGR for the regular growth rate for each country and the percentage of capacity achieved in 2025. The calculated CAGR of Chile and Argentina are similar. Australia has a high CAGR, which allows for significant growth until 2025. Australia will probably stop its production growth in 2019 as it will reach $100 \%$ of its production capacity. In the case of China, its CAGR from 2005 to 2015 is zero. It shows that China does not have any growth in its lithium production.

To achieve $100 \%$ capacity until 2025 , the CAGR of each country shall be calculated depending on how close they are to the $100 \%$ capacity. The countries with higher capacity are Argentina, Australia, and Chile, with 51, 65 and $62 \%$ respectively. China has $20 \%$ of capacity. This means that the CAGR needed for Argentina, Australia, and Chile is less than the CAGR needed by China due to the difference in the $100 \%$ capacity desired. Table $\mathbf{3}$ shows CAGR calculated for each country at $100 \%$ of their lithium production capacity in 2025 . 


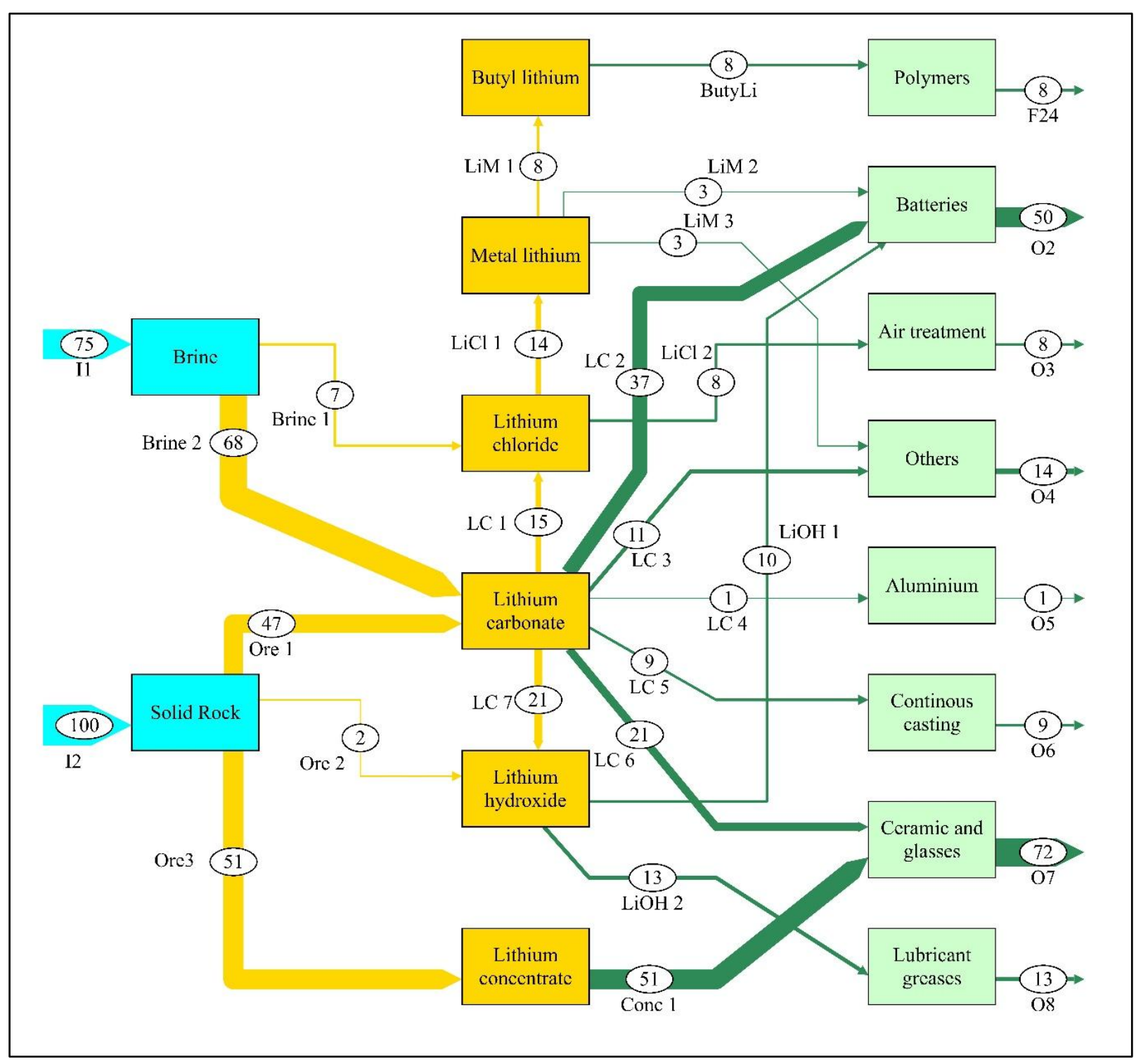

Fig. (4). Material flow of lithium in 2015.

The CAGR comparison of Reg scenario and FC scenario is presented in Fig. (6). Australia presents the same CAGR calculated in both scenarios because with its regular growth, Australia shall reach a $100 \%$ capacity. Argentina needs to increase its CAGR 3 times and Chile needs to increase its CAGR 2.3 times to reach a $100 \%$ capacity. In the case of China, they have no capacity in Reg scenario and need a $22 \%$ increase for the FC scenario. This is due to the low capacity that China has (Table 1), and this percentage represents that China does not extract the reserves of lithium that they possess, but they import lithium brine and concentrate to convert into other compounds of the lithium supply chain. As Xin Sun mentions, the flow of minerals from China is low but the flow of basic chemicals from China is much bigger [5].

Fig. (7) presents the historical global lithium production for each country until 2015 . Then, the data is calculated with the model using the CAGR of Tables 2 and 3. In 2019, a continuous line shown at 118000 tonnes of LCE produced from Australia represents the $100 \%$ capacity of Australia. It has been mentioned that Australia would reach a $100 \%$ capacity in both scenarios according to the CAGR that they have historically. The rest of the countries may reach $100 \%$ capacity until 2025 . 


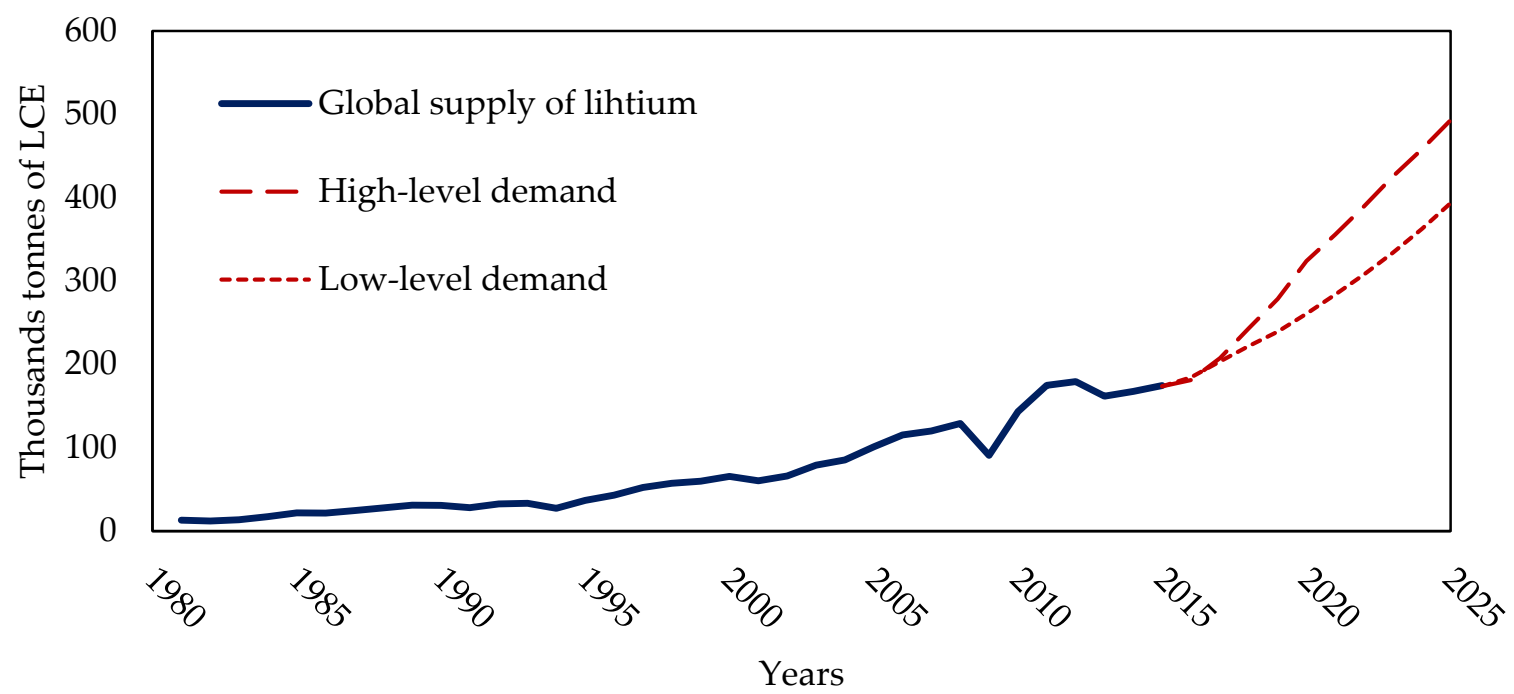

Fig. (5). Supply and demand of lithium [41, 47].

Table 2. Calculated CAGR in Reg Scenario and capacity increase from 2015 to 2025.

\begin{tabular}{|c|c|c|c|}
\hline \multirow{2}{*}{ Country } & CAGR (Scenario Reg) & \multicolumn{2}{|c|}{ Capacity of Lithium Supply } \\
\cline { 2 - 4 } & $2005-2015(\%)$ & $2015(\%)$ & $2025(\%)$ \\
\hline Argentina & 3 & 51 & 67 \\
\hline Australia & 11 & 65 & 100 \\
\hline Chile & 2 & 62 & 71 \\
\hline China & 0 & 20 & 20 \\
\hline
\end{tabular}

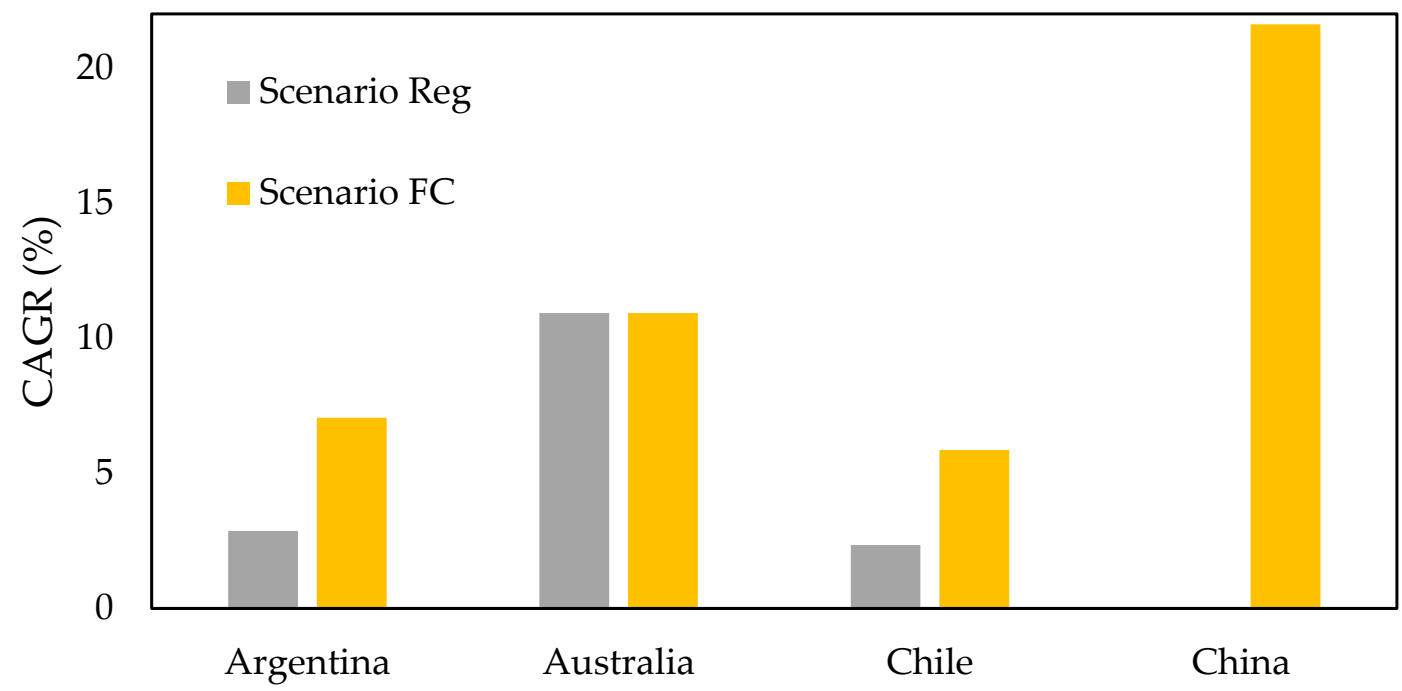

Fig. (6). CAGR calculated for major lithium producers. 
Table 3. Calculated CAGR with full capacity (FC) and capacity increase from 2015 to 2025.

\begin{tabular}{|c|c|c|c|}
\hline \multirow{2}{*}{ Country } & CAGR (Scenario FC) & \multicolumn{2}{|c|}{ Capacity of Lithium Supply } \\
\cline { 2 - 4 } & $(\%)$ & $2015(\%)$ & $2025(\%)$ \\
\hline Argentina & 7 & 51 & 100 \\
\hline Australia & 11 & 65 & 100 \\
\hline Chile & 6 & 62 & 100 \\
\hline China & 22 & 20 & 100 \\
\hline
\end{tabular}

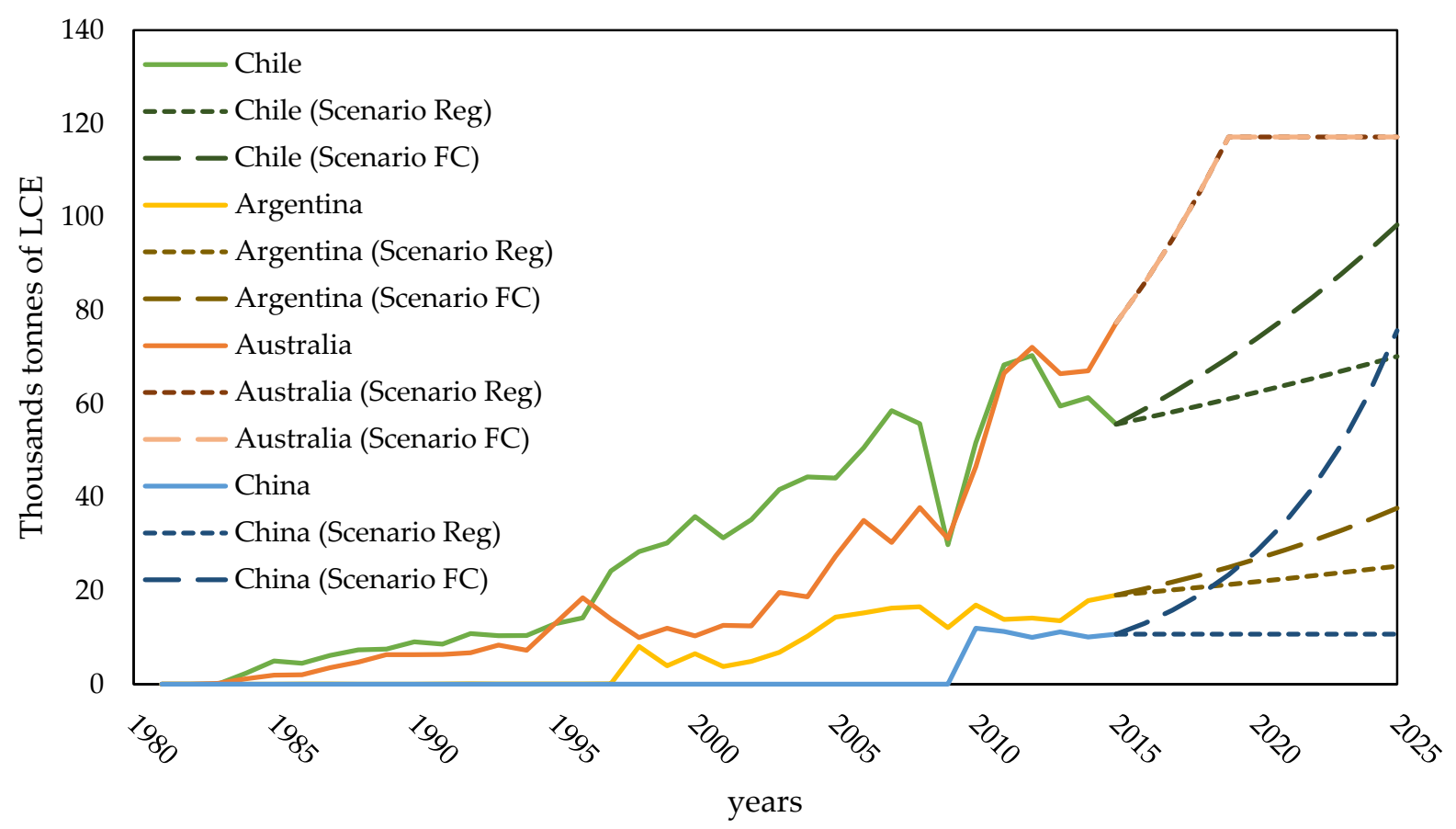

Fig. (7). Different scenarios of lithium production for major producers.

In the scenario building section, three scenarios are mentioned; NP, CP, and UCP. Each one of them is described in the next paragraphs.

Fig. (8) shows the results of a comparison between supply and demand for NP scenarios. The low level-demand can be met in 2025 with the FC scenario but not with the Reg scenario. The Reg scenario reaches around 354 thousand tonnes of LCE covering $90 \%$ of the low-level demand. The high-level demand is not covered by any of the NP scenarios; Reg scenario reaches $72 \%$ of the high-level demand and FC scenario reaches $83 \%$ of the high-level demand, respectively. These results indicate that even with a full capacity production, the demand still overpasses the possible supply, and therefore, new projects are required.

Fig. (9) presents the dynamics of the global supply and demand for lithium, according to the Committed Projects (CP) scenarios. The result shows that low-level demand is overpassed by Reg scenario and FC scenario. However, none of the scenarios reach high-level demand. Reg scenario covers $84 \%$ of the high-level demand and FC scenario covers $95 \%$ of high-level demand. These results indicate that with the committed projects, only the low-level demand is covered. As there is a possibility for the high-level demand to occur, it poses a risk on the supply of lithium with $\mathrm{CP}$ scenarios. 


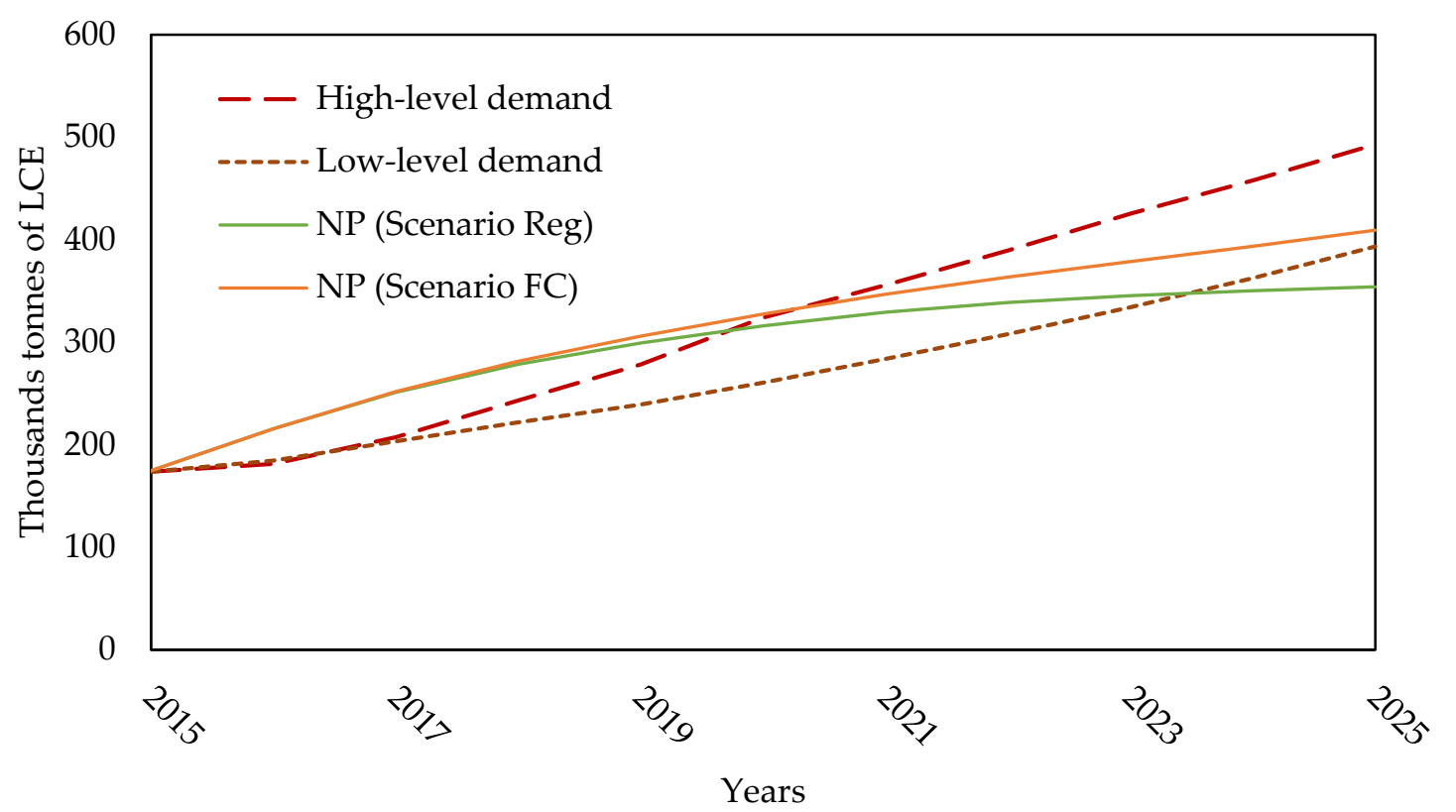

Fig. (8). NP Scenarios compared with the two demand scenarios.

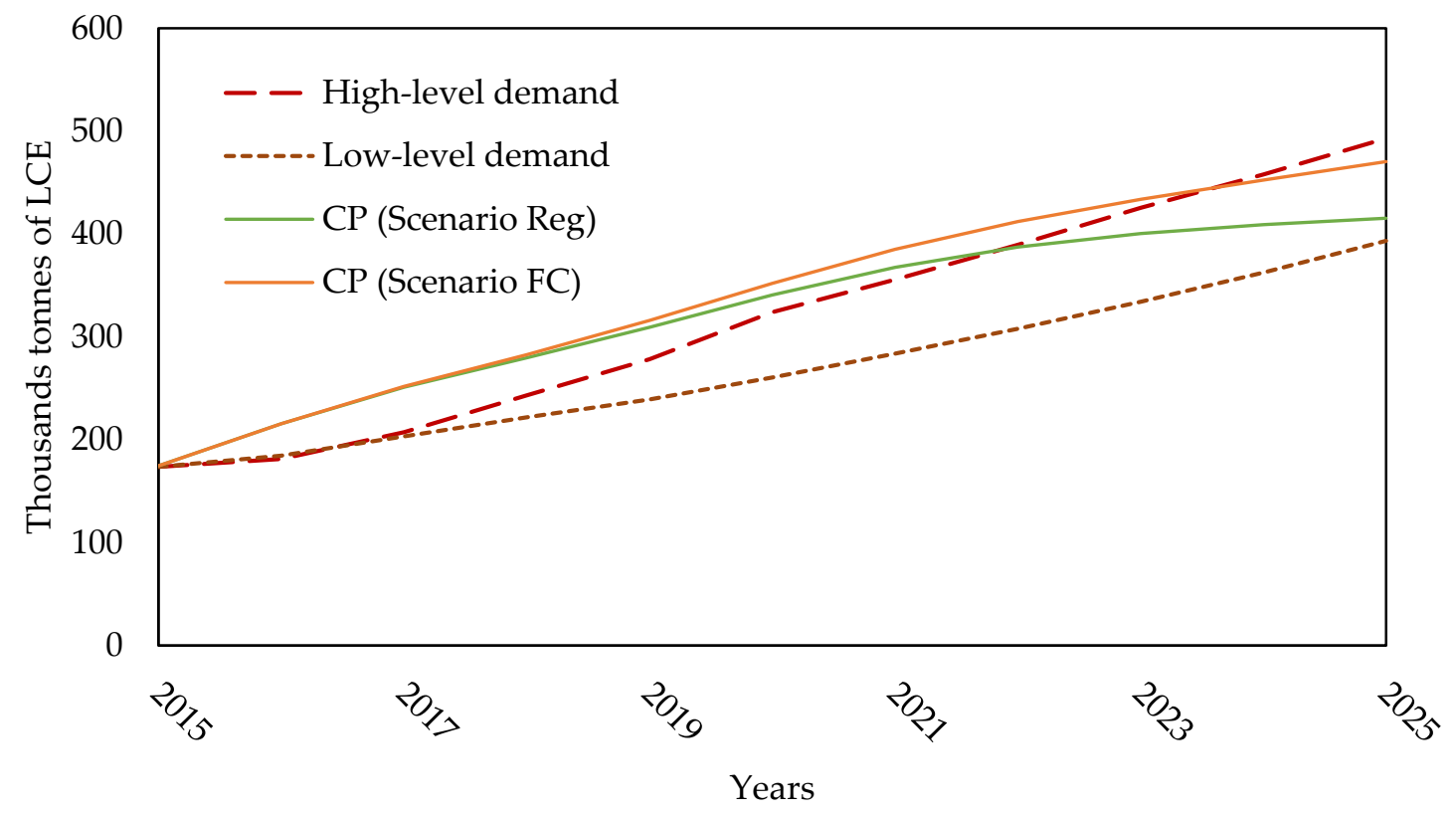

Fig. (9). Committed projects scenarios compared with the two demand scenarios.

Fig. (10) presents the dynamics of the global supply and demand for lithium, according to Un-Committed Projects (UCP) scenarios. Both the low-level demand and the high-level demand are overpassed by both scenarios of UCP. The result shows that Reg scenario reaches around 529 thousand tonnes of LCE by 2025 . It exceeds the low-level demand by $34 \%$ and the high-level demand by $7 \%$. The FC scenario reaches around 584 thousand tonnes of LCE by 2025. This scenario exceeds the high-level demand by $18 \%$ and the low-level demand by $48 \%$. 


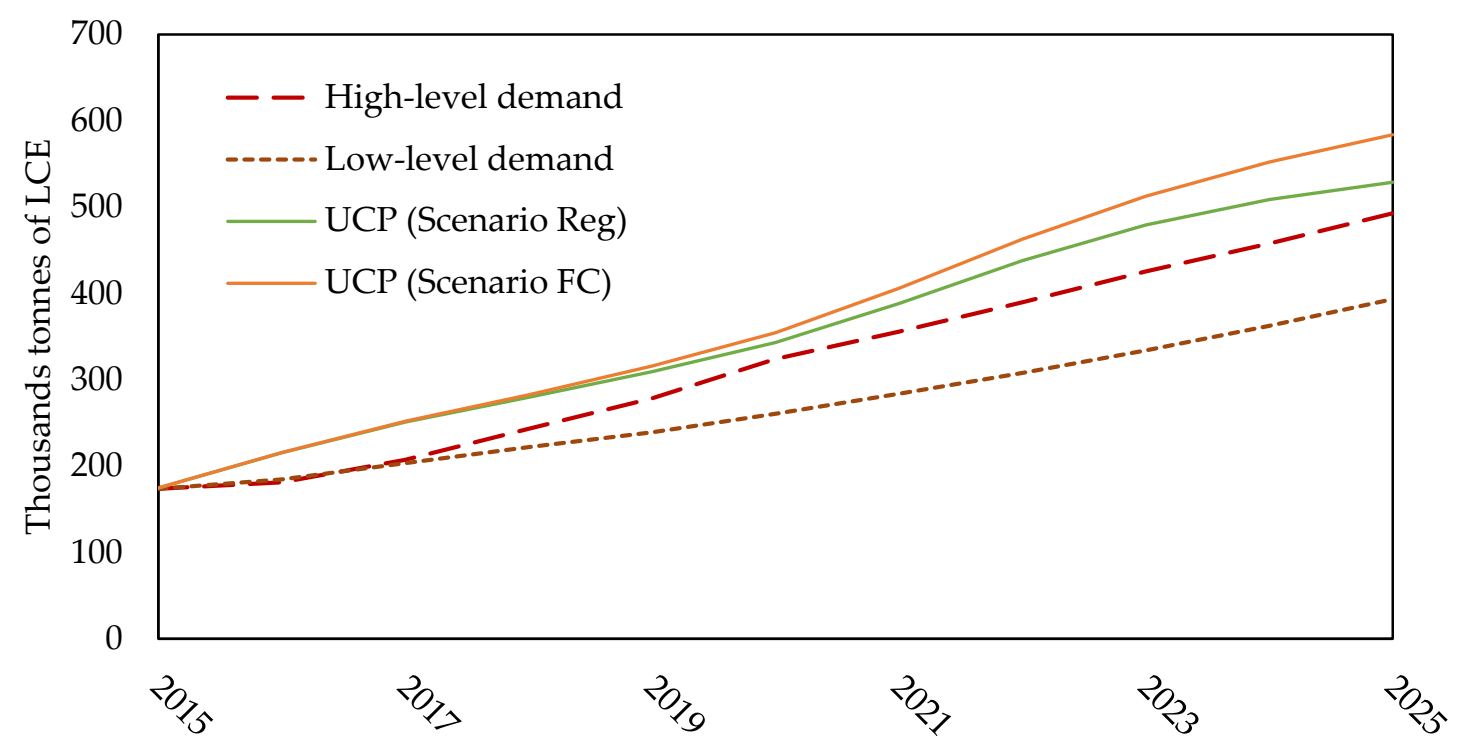

Fig. (10). Un-committed projects scenarios compared with the two demand scenarios.

\section{CONCLUSION}

The present research addresses the question if the global production of lithium will be sufficient to cover the uncertain demand by 2025. The analysis has been performed for three different situations related to the realization of mining projects by the main lithium producers: Chile, Australia, Argentina, and China. The situations under consideration are no new projects in the portfolio, committed projects for 2018, and uncommitted projects for 2020. We considered two scenarios for estimating the growth rate of lithium production in the future: a regular growth rate and a growth rate by assuming the full capacity of lithium production by each major supplier.

Based on the result of the proposed dynamic model, the scenario Reg was able to cover $72 \%$ of the high-level demand and $90 \%$ of the low-level demand by 2025 if we consider no new projects in the portfolio. In this case, the scenario FC covered $83 \%$ of the high-level demand and $100 \%$ of the lowlevel demand by 2025 , exceeding it by just $4 \%$. Considering committed projects for 2018 , the scenario Reg covered $84 \%$ of the high-level demand and $100 \%$ of the low-level demand, exceeding it by $6 \%$. The scenario FC covered $95 \%$ of the highlevel demand and $100 \%$ of the low-level demand, exceeding it by $20 \%$. Finally, considering uncommitted projects for 2020 , the scenario Reg covered $100 \%$ of both low-level and highlevel demands. It exceeds the low-level demand by $34 \%$ and the high-level demand by $7 \%$. The scenario FC also covered $100 \%$ of both low and high demands, exceeding the high-level demand by $18 \%$ and the low-level demand by $48 \%$.

Considering that UCP scenarios cover both low and highlevel demands, intermediate scenarios between committed projects and un-committed projects could be combined to meet both the demands. This means that the consideration of committed projects in some countries in combination with uncommitted projects in other countries could cover $100 \%$ of the demand without excess, as in the case of UCP scenarios.
It is not possible to maintain the current production of lithium in order to satisfy the increasing demand by 2025 . The supply of lithium must grow in the coming years either by increasing the production capacity of suppliers or by construction of new processing plants. On the other hand, only by considering uncommitted projects for 2020 , both scenarios cover the high-level demand by 2025 . Therefore, considering a scenario where electric vehicles and energy storage markets lead to low-carbon emissions and break away from traditional infrastructure network, a high-level demand for lithium can be expected. Therefore, the new uncommitted projects of lithium mining and production should start to operate at least in 2020 to cover this increasing high-level demand.

\section{CONSENT FOR PUBLICATION}

Not applicable.

\section{AVAILABILITY OF DATA AND MATERIALS}

Not applicable.

\section{FUNDING}

This study is supported by National Agency for Research and Development ANID (Fondecyt 1180826), Chile.

\section{CONFLICT OF INTEREST}

The author declares no conflict of interest, financial or otherwise.

\section{ACKNOWLEDGEMENTS}

The authors acknowledge support from LUT University on the stock and flow model simulations. 
APPENDIX A

Table A1. Equations and calculation processes for lithium supply chain model.

\begin{tabular}{|c|c|c|c|c|}
\hline Variable & Term & Unit & Equation & \begin{tabular}{|c|} 
Type of \\
variable \\
\end{tabular} \\
\hline$S_{G}(t)$ & $\begin{array}{l}\text { Global } \\
\text { supply of } \\
\text { chemical } \\
\text { lithium }\end{array}$ & $\begin{array}{c}\text { Tonne } \\
\text { LCE }\end{array}$ & $\begin{aligned} \int_{t 0}^{t}\left(P_{\text {Chile }}(t)+\right. & P_{\text {Australia }}(t)+P_{\text {Argentina }}(t)+P_{\text {China }}(t) \\
& \left.+P_{\text {Rest of World }}(t)-P r_{\text {Brine }}(t)-P r_{\text {Ore }}(t)\right) d t \\
& +S_{G}\left(t_{0}\right)\end{aligned}$ & Stock \\
\hline$P_{\text {Chile }}(t)$ & \begin{tabular}{|c|} 
Lithium \\
primary \\
production \\
by Chile
\end{tabular} & $\begin{array}{c}\text { Tonne } \\
\text { LCE }\end{array}$ & $P_{\mathrm{Li}_{2} \mathrm{CO}_{3} \mathrm{C} \text { Chile }}(t)+P_{\text {LiCl_Chile }}(t)+P_{\text {LiOH_Chile }_{-}}(t)$ & Flow \\
\hline$P_{\text {Australia }}(t)$ & $\begin{array}{l}\begin{array}{l}\text { Lithium } \\
\text { primary } \\
\text { production } \\
\text { by } \\
\text { Australia }\end{array} \\
\end{array}$ & $\begin{array}{c}\text { Tonne } \\
\text { LCE }\end{array}$ & $P_{\text {Ore_Australia }}(t)$ & Flow \\
\hline$P_{\text {Argentina }}(t)$ & $\begin{array}{l}\text { Lithium } \\
\text { primary } \\
\text { production } \\
\text { by } \\
\text { Argentina } \\
\end{array}$ & $\begin{array}{c}\text { Tonne } \\
\text { LCE }\end{array}$ & $P_{\text {LiCl_Argentina }}(t)+P_{\mathrm{Li}_{2} \mathrm{CO}_{3_{-}} \text {Argentina }}(t)+P_{\text {Ore_Argentina }_{-}}(t)$ & Flow \\
\hline$P_{\text {China }}(t)$ & $\begin{array}{c}\text { Lithium } \\
\text { primary } \\
\text { production } \\
\text { by China } \\
\end{array}$ & $\begin{array}{c}\text { Tonne } \\
\text { LCE }\end{array}$ & $P_{\mathrm{Li}_{2} \mathrm{CO}_{3}{ }_{3} \mathrm{China}}(t)$ & Flow \\
\hline$P_{\text {Rest of World }}(t)$ & 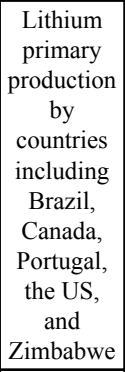 & $\begin{array}{c}\text { Tonne } \\
\text { LCE }\end{array}$ & $\begin{array}{c}P_{\text {Concentrate_Brazil }}(t)+P_{\text {Ore_Zimbabwe }}(t)+P_{\text {Ore_Portugal }}(t) \\
+P_{\text {Ore_Canada }}(t)+P_{\text {Brine_US }}(t)\end{array}$ & Flow \\
\hline$P r_{\text {Brine }}(t)$ & $\begin{array}{l}\text { Brine } \\
\text { Process }\end{array}$ & $\begin{array}{c}\text { Tonne } \\
\text { LCE }\end{array}$ & $\alpha_{1} * S_{G}(t)$ & Flow \\
\hline$P r_{\text {Ore }}(t)$ & $\begin{array}{c}\text { Ore } \\
\text { Process }\end{array}$ & \begin{tabular}{c|} 
Tonne \\
LCE
\end{tabular} & $\alpha_{2} * S_{G}(t)$ & Flow \\
\hline$S_{\text {Brine }}(t)$ & $\begin{array}{c}\text { Stock of } \\
\text { global } \\
\text { Brine }\end{array}$ & $\begin{array}{c}\text { Tonne } \\
\text { LCE }\end{array}$ & $\int_{t 0}^{t}\left(P r_{\text {Brine }}(t)-P r_{\text {LiCl_1 }}(t)-P r_{L_{2} C_{3_{3} 2}}(t)\right) d t+S_{\text {Brine }}\left(t_{0}\right)$ & Stock \\
\hline$S_{\text {Ore }}(t)$ & $\begin{array}{c}\text { Stock of } \\
\text { global Ore }\end{array}$ & $\begin{array}{c}\text { Tonne } \\
\text { LCE }\end{array}$ & 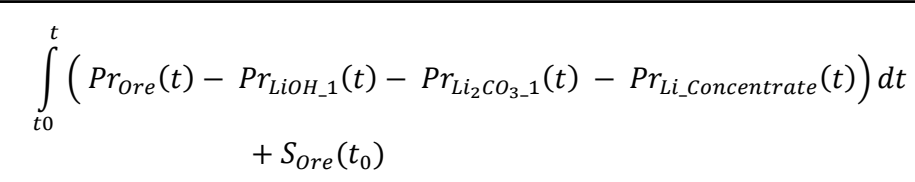 & Stock \\
\hline$\overline{P r_{L i C l} I}(t)$ & \begin{tabular}{|} 
Lithium \\
chloride \\
process \\
from brine \\
\end{tabular} & $\begin{array}{c}\text { Tonne } \\
\text { LCE }\end{array}$ & $\beta_{1} * S_{\text {Brine }}(t)$ & Flow \\
\hline$P r_{L_{2} C_{3} O_{3}}(t)$ & \begin{tabular}{|} 
Lithium \\
carbonate \\
process \\
from brine \\
\end{tabular} & $\begin{array}{c}\text { Tonne } \\
\text { LCE }\end{array}$ & $\gamma_{2} * S_{\text {Brine }}(t)$ & Flow \\
\hline $\operatorname{Pr}_{\mathrm{LiOH}_{-} I}(t)$ & $\begin{array}{l}\text { Lithium } \\
\text { hydroxide } \\
\text { process } \\
\text { from ore }\end{array}$ & $\begin{array}{c}\text { Tonne } \\
\text { LCE }\end{array}$ & $\rho_{1} * S_{\text {Ore }}(t)$ & Flow \\
\hline
\end{tabular}




\begin{tabular}{|c|c|c|c|c|}
\hline 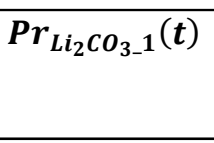 & \begin{tabular}{|} 
Lithium \\
carbonate \\
process \\
from ore
\end{tabular} & $\begin{array}{c}\text { Tonne } \\
\text { LCE }\end{array}$ & $\gamma_{1} * S_{\text {Ore }}(t)$ & Flow \\
\hline$P r_{L i-C o n c e n t r u t e}(t)$ & \begin{tabular}{|} 
Lithium \\
concentrate \\
process \\
from ore
\end{tabular} & \begin{tabular}{|c|} 
Tonne \\
LCE
\end{tabular} & $\delta * S_{\text {Ore }}(t)$ & Flow \\
\hline$S_{L_{i} \text { Concentrate }}(t)$ & $\begin{array}{c}\text { Stock of } \\
\text { lithium } \\
\text { concentrate }\end{array}$ & \begin{tabular}{|c|} 
Tonne \\
LCE
\end{tabular} & $\int_{t 0}^{t}\left(P r_{L i_{-} \text {Concentrate }}(t)-P r_{C G_{-} 2}(t)\right) d t+S_{\text {Li_Concentrate }}\left(t_{0}\right)$ & Stock \\
\hline$P r_{C G_{-} 2}(t)$ & \begin{tabular}{|c|} 
Ceramic \\
and glass \\
process \\
from \\
lithium \\
concentrate \\
\end{tabular} & \begin{tabular}{|c|} 
Tonne \\
LCE
\end{tabular} & $I_{2} * S_{\text {Li_Concentrate }}(t)$ & Flow \\
\hline$S_{\text {LiOH }}(t)$ & \begin{tabular}{|c|} 
Stock of \\
lithium \\
hydroxide
\end{tabular} & \begin{tabular}{|c|} 
Tonne \\
LCE
\end{tabular} & $\int_{t 0}^{t}\left(P r_{L_{i O H_{-} 1}}(t)+P r_{L_{0 H_{-} 2}}(t)-P r_{L G}(t)-P r_{B_{-} 2}(t)-\right) d t+S_{L i O H}\left(t_{0}\right)$ & Stock \\
\hline $\operatorname{Pr}_{\text {LiOH_Z }_{-}(t)}$ & \begin{tabular}{|c|} 
Lithium \\
hydroxide \\
process \\
from \\
lithium \\
carbonate
\end{tabular} & \begin{tabular}{|c|} 
Tonne \\
LCE
\end{tabular} & $\rho_{2} * S_{L i_{2} C O_{3}}(t)$ & Flow \\
\hline$P r_{B_{-} 2}(t)$ & \begin{tabular}{|c|} 
Battery \\
process \\
from \\
lithium \\
hydroxide \\
\end{tabular} & \begin{tabular}{|c|} 
Tonne \\
LCE
\end{tabular} & $k_{2} * S_{\mathrm{LiOH}}(t)$ & Flow \\
\hline$S_{\mathrm{Li}_{2} \mathrm{CO}_{3}}(\mathrm{t})$ & \begin{tabular}{|c|}
$\begin{array}{c}\text { Stock of } \\
\text { lithium } \\
\text { carbonate }\end{array}$ \\
\end{tabular} & \begin{tabular}{|c|} 
Tonne \\
LCE
\end{tabular} & 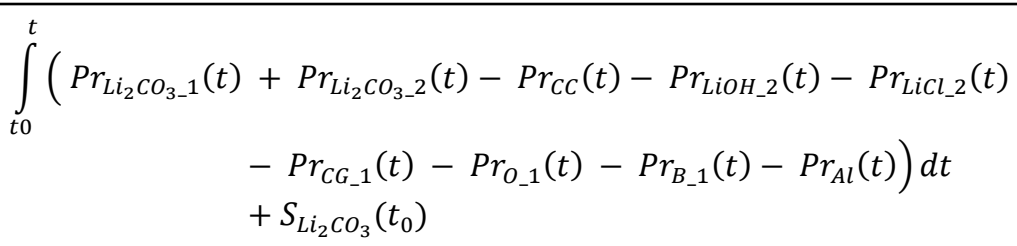 & Stock \\
\hline $\boldsymbol{P r}_{L G}(t)$ & \begin{tabular}{|c|} 
Lubricant \\
and greases \\
process \\
from \\
lithium \\
hydroxide
\end{tabular} & \begin{tabular}{|c|} 
Tonne \\
LCE
\end{tabular} & $C * S_{\mathrm{LiOH}}(t)$ & Flow \\
\hline$P r_{c c}(t)$ & \begin{tabular}{|c|} 
Continuous \\
casting \\
process \\
from \\
lithium \\
carbonate
\end{tabular} & \begin{tabular}{|c|} 
Tonne \\
LCE
\end{tabular} & $D * S_{\mathrm{Li}_{2} \mathrm{CO}_{3}}(t)$ & Flow \\
\hline$P r_{L i C C_{2} 2}(t)$ & 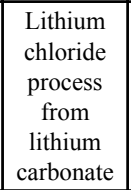 & \begin{tabular}{|c|} 
Tonne \\
LCE
\end{tabular} & $\beta_{2} * S_{L i_{2} \mathrm{CO}_{3}}(t)$ & Flow \\
\hline$P r_{O_{-} I}(t)$ & \begin{tabular}{|c|} 
Other \\
products \\
process \\
from \\
lithium \\
carbonate
\end{tabular} & \begin{tabular}{|c|} 
Tonne \\
LCE
\end{tabular} & $O_{1} * S_{L i_{2} \mathrm{CO}_{3}}(t)$ & Flow \\
\hline $\boldsymbol{P r _ { C G _ { - 1 } } ( t )}$ & \begin{tabular}{|c|} 
Ceramic \\
and glass \\
process \\
from \\
lithium \\
carbonate
\end{tabular} & \begin{tabular}{|c|} 
Tonne \\
LCE
\end{tabular} & $I_{1} * S_{L_{2} C O_{3}}(t)$ & Flow \\
\hline
\end{tabular}




\begin{tabular}{|c|c|c|c|c|}
\hline$P r_{B_{-} I}(t)$ & \begin{tabular}{|c|} 
Battery \\
process \\
from \\
lithium \\
carbonate \\
\end{tabular} & $\begin{array}{c}\text { Tonne } \\
\text { LCE }\end{array}$ & $k_{1} * S_{L_{2} \mathrm{CO}_{3}}(t)$ & Flow \\
\hline$P r_{A l}(t)$ & \begin{tabular}{|c|} 
Aluminum \\
process \\
from \\
lithium \\
carbonate
\end{tabular} & \begin{tabular}{|c|} 
Tonne \\
LCE
\end{tabular} & $A * S_{\mathrm{Li}_{2} \mathrm{CO}_{3}}(t)$ & Flow \\
\hline$S_{c c}(t)$ & \begin{tabular}{|c|} 
Stock of \\
continuous \\
casting
\end{tabular} & $\begin{array}{c}\text { Tonne } \\
\text { LCE }\end{array}$ & $\int_{t 0}^{t}\left(\operatorname{Pr}_{C C}(t)\right) d t+S_{C C}\left(t_{0}\right)$ & Stock \\
\hline $\operatorname{Pr}_{A T}(t)$ & \begin{tabular}{|c|} 
Air \\
treatment \\
process \\
from \\
lithium \\
chloride \\
\end{tabular} & $\begin{array}{c}\text { Tonne } \\
\text { LCE }\end{array}$ & $A T * S_{L_{2} \mathrm{CO}_{3}}(t)$ & Flow \\
\hline$S_{A T}(t)$ & \begin{tabular}{|c|} 
Stock of \\
Air \\
treatment
\end{tabular} & $\begin{array}{c}\text { Tonne } \\
\text { LCE }\end{array}$ & $\int_{t 0}^{t}\left(P r_{A T}(t)\right) d t+S_{A T}\left(t_{0}\right)$ & Stock \\
\hline$S_{L i C l}(t)$ & $\begin{array}{l}\text { Stock of } \\
\text { lithium } \\
\text { chloride }\end{array}$ & \begin{tabular}{|c|} 
Tonne \\
LCE
\end{tabular} & $\int_{t 0}^{t}\left(P r_{L i C l \_1}(t)+P r_{L i C l \_}(t)-P r_{A T}(t)-P r_{L i}(t)\right) d t+S_{L i C l}\left(t_{0}\right)$ & Stock \\
\hline$P r_{L i}(t)$ & $\begin{array}{l}\text { Lithium } \\
\text { metal } \\
\text { process } \\
\text { from } \\
\text { lithium } \\
\text { chloride }\end{array}$ & \begin{tabular}{|c|} 
Tonne \\
LCE
\end{tabular} & $L * S_{L i C l}(t)$ & Flow \\
\hline$S_{L i}(t)$ & $\begin{array}{c}\text { Stock of } \\
\text { lithium } \\
\text { metal }\end{array}$ & \begin{tabular}{|c|} 
Tonne \\
LCE
\end{tabular} & $\int_{t 0}^{t}\left(P r_{L i}(t)-P r_{B u t y l}(t)-P r_{O_{-} 2}(t)-P r_{B_{-} 3}(t)\right) d t+S_{L i}\left(t_{0}\right)$ & Stock \\
\hline$P r_{B u t y}(t)$ & $\begin{array}{l}\text { Butyl } \\
\text { lithium } \\
\text { process } \\
\text { from } \\
\text { lithium } \\
\text { metal } \\
\end{array}$ & $\begin{array}{c}\text { Tonne } \\
\text { LCE }\end{array}$ & $B u * S_{L i}(t)$ & Flow \\
\hline $\operatorname{Pr}_{\mathrm{O}_{-2} 2}(t)$ & $\begin{array}{l}\text { Other } \\
\text { products } \\
\text { process } \\
\text { from } \\
\text { lithium } \\
\text { metal } \\
\end{array}$ & $\begin{array}{c}\text { Tonne } \\
\text { LCE }\end{array}$ & $O_{2} * S_{L i}(t)$ & Flow \\
\hline $\operatorname{Pr}_{B_{-3} 3}(t)$ & $\begin{array}{l}\text { Battery } \\
\text { process } \\
\text { from } \\
\text { lithium } \\
\text { metal }\end{array}$ & \begin{tabular}{|c|} 
Tonne \\
LCE
\end{tabular} & $k_{3} * S_{L i}(t)$ & Flow \\
\hline$S_{o}(t)$ & $\begin{array}{l}\text { Stock of } \\
\text { Other } \\
\text { products }\end{array}$ & \begin{tabular}{|c|} 
Tonne \\
LCE
\end{tabular} & $\int_{t 0}^{t}\left(P r_{O_{-} 1}(t)+P r_{O_{-} 2}(t)\right) d t+S_{O}\left(t_{0}\right)$ & Stock \\
\hline$\overline{S_{A l}(t)}$ & \begin{tabular}{|c|} 
Stock of \\
Aluminum
\end{tabular} & \begin{tabular}{|c|} 
Tonne \\
LCE
\end{tabular} & $\int_{t 0}^{t}\left(\operatorname{Pr}_{A l}(t)\right) d t+S_{A l}\left(t_{0}\right)$ & Stock \\
\hline$S_{C G}(t)$ & \begin{tabular}{|c|} 
Stock of \\
ceramic \\
and glass
\end{tabular} & \begin{tabular}{|c|} 
Tonne \\
LCE
\end{tabular} & $\int_{t 0}^{t}\left(P r_{C G_{-} 1}(t)+P r_{C G_{-} 2}(t)\right) d t+S_{C G}\left(t_{0}\right)$ & Stock \\
\hline $\operatorname{Pr}_{p}(t)$ & $\begin{array}{c}\text { Polymer } \\
\text { process } \\
\text { from butyl } \\
\text { lithium }\end{array}$ & \begin{tabular}{c|} 
Tonne \\
LCE
\end{tabular} & $P * S_{\text {Butyl }}(t)$ & Flow \\
\hline
\end{tabular}




\begin{tabular}{|c|c|c|c|c|}
\hline$S_{\text {Butyy }}(t)$ & $\begin{array}{l}\text { Stock of } \\
\text { butyl } \\
\text { lithium }\end{array}$ & \begin{tabular}{|c|} 
Tonne \\
LCE
\end{tabular} & $\int_{t 0}^{t}\left(P r_{C G_{-} 1}(t)+P r_{C G_{-} 2}(t)\right) d t+S_{C G}\left(t_{0}\right)$ & Stock \\
\hline$S_{P}(t)$ & $\begin{array}{l}\text { Stock of } \\
\text { polymer }\end{array}$ & \begin{tabular}{|c|} 
Tonne \\
LCE
\end{tabular} & $\int_{t 0}^{t}\left(\operatorname{Pr}_{P}(t)\right) d t+S_{P}\left(t_{0}\right)$ & Stock \\
\hline$S_{L G}(t)$ & \begin{tabular}{|c|} 
Stock of \\
lubricant \\
and grease
\end{tabular} & \begin{tabular}{|c|} 
Tonne \\
LCE
\end{tabular} & $\int_{t 0}^{t}\left(P r_{L G}(t)\right) d t+S_{L G}\left(t_{0}\right)$ & Stock \\
\hline$S_{B}(t)$ & $\begin{array}{l}\text { Stock of } \\
\text { batteries }\end{array}$ & \begin{tabular}{|c|} 
Tonne \\
LCE
\end{tabular} & $\int_{t 0}^{t}\left(P r_{B_{-} 1}(t)+P r_{B_{-} 2}(t)+P r_{B_{-} 3}(t)\right) d t+S_{B}\left(t_{0}\right)$ & Stock \\
\hline
\end{tabular}

Table A2. Data sources for all inputs of the proposed model.

\begin{tabular}{|c|c|c|c|c|c|}
\hline Parameter (auxiliary) & Description & Unit & Value Range & Time & Data Sources \\
\hline$P_{\mathrm{Li}_{2} \mathrm{CO}_{3 \_} \mathrm{Chile}}(\mathrm{t})$ & Lithium carbonate primary production by Chile & Tonne LCE & $2326-62,002$ & $1984-2015$ & {$[18]-[39]$} \\
\hline$P_{\text {LiCl_Chile }}(t)$ & Lithium chloride primary production by Chile & Tonne LCE & $416-3674$ & $2004-2015$ & {$[21,38-48]$} \\
\hline$P_{\text {LiOH_Chile }}(t)$ & Lithium hydroxide primary production by Chile & Tonne LCE & $451-5190$ & $2005-2015$ & $\begin{array}{l}{[21]-[28],} \\
{[30]-[32]}\end{array}$ \\
\hline$P_{\text {Ore_Australia }}(t)$ & Ore production by Australia & Tonne LCE & $14-77368$ & $1982-2015$ & {$[18]-[39]$} \\
\hline$P_{\text {LiCl_Argentina }}(\boldsymbol{t})$ & Lithium chloride primary production by Argentina & Tonne LCE & $2105-7434$ & $1998-2015$ & $\begin{array}{l}{[19]-[28],} \\
{[30]-[32],} \\
{[35]-[39]}\end{array}$ \\
\hline$P_{L_{2} C_{3} O_{3} \text { Argentina }}(t)$ & Lithium carbonate primary production by Argentina & Tonne LCE & 906-14137 & $1998-2015$ & $\begin{array}{l}{[19]-[28],} \\
{[30]-[32],} \\
{[35]-[39]}\end{array}$ \\
\hline$P_{\text {Ore_Argentina }}(t)$ & Ore production by Argentina & Tonne LCE & $3-110$ & 1981-1997 & {$[18]-[39]$} \\
\hline$P_{\text {Concentrate_Brazil }}(t)$ & Concentrate production by Brazil & Tonne LCE & $75-2515$ & $1981-2015$ & {$[18]-[39]$} \\
\hline$P_{\text {Ore_Zimbabwe }}(t)$ & Ore production by Zimbabwe & Tonne LCE & $1451-8368$ & $1981-2015$ & {$[18]-[39]$} \\
\hline Pore_Portugal $(t)$ & Ore production by Portugal & Tonne LCE & $95-6333$ & $1981-2015$ & {$[18]-[39]$} \\
\hline$P_{\mathrm{Li}_{2} \mathrm{CO}_{3 \_} \mathrm{China}}(\mathrm{t})$ & Carbonate production by China & Tonne LCE & $10000-12000$ & $2010-2015$ & $\begin{array}{l}{[26]-[28]} \\
{[30]-[32]}\end{array}$ \\
\hline$P_{\text {Ore_Canada }}(t)$ & Ore production by Canada & Tonne LCE & $15-3553$ & $1984-2009$ & {$[18]-[39]$} \\
\hline$P_{\text {Brine_US }}(t)$ & Brine production by the US & Tonne LCE & $5000-6000$ & $2016-2025$ & [41] \\
\hline$\alpha_{1}$ & Brine coefficient & $\%$ & $23-78$ & 1984-2025 & [18]-[39], [41] \\
\hline$\alpha_{2}$ & Ore coefficient & $\%$ & $22-77$ & $1984-2025$ & {$[18]-[39],[41]$} \\
\hline $\boldsymbol{\beta}_{1}$ & Lithium chloride coefficient from brine process & $\%$ & 9 & 2015 & [40] \\
\hline$\gamma_{2}$ & Lithium carbonate coefficient from brine process & $\%$ & 91 & 2015 & [40] \\
\hline$\rho_{1}$ & Lithium hydroxide coefficient from ore process & $\%$ & 9 & 2015 & [40] \\
\hline$\gamma_{1}$ & Lithium carbonate coefficient from ore process & $\%$ & 68 & 2015 & [40] \\
\hline$\delta$ & Lithium concentrate coefficient from ore process & $\%$ & 23 & 2015 & [40] \\
\hline$\overline{I_{2}}$ & $\begin{array}{l}\text { Ceramic and glass coefficient from lithium concentrate } \\
\text { process }\end{array}$ & $\%$ & 100 & 2015 & [40] \\
\hline$C$ & $\begin{array}{c}\text { Lubricant and greases coefficient from lithium } \\
\text { hydroxide process }\end{array}$ & $\%$ & 57 & 2015 & [40] \\
\hline$D$ & $\begin{array}{l}\text { Continuous casting coefficient from lithium carbonate } \\
\text { process }\end{array}$ & $\%$ & 8 & 2015 & [40] \\
\hline
\end{tabular}




\begin{tabular}{|c|c|c|c|c|c|}
\hline $\boldsymbol{\beta}_{2}$ & $\begin{array}{c}\text { Lithium chloride coefficient from lithium carbonate } \\
\text { process }\end{array}$ & $\%$ & 13 & 2015 & {$[40]$} \\
\hline $\boldsymbol{O}_{I}$ & $\begin{array}{c}\text { Other products coefficient from lithium carbonate } \\
\text { process }\end{array}$ & $\%$ & 10 & 2015 & {$[40]$} \\
\hline$I_{1}$ & $\begin{array}{c}\text { Ceramic and glass coefficient from lithium carbonate } \\
\text { process }\end{array}$ & $\%$ & 18 & 2015 & {$[40]$} \\
\hline$k_{2}$ & Battery coefficient from lithium hydroxide process & $\%$ & 43 & 2015 & {$[40]$} \\
\hline$k_{l}$ & Battery coefficient from lithium carbonate process & $\%$ & 32 & 2015 & {$[40]$} \\
\hline$A$ & Aluminum coefficient from lithium carbonate process & $\%$ & 1 & 2015 & {$[40]$} \\
\hline$A T$ & Air treatment coefficient from lithium chloride process & $\%$ & 36 & 2015 & {$[40]$} \\
\hline $\mathbf{L}$ & Lithium metal coefficient from lithium chloride process & $\%$ & 64 & 2015 & {$[40]$} \\
\hline$O_{2}$ & Other products coefficient from lithium metal process & $\%$ & 22 & 2015 & {$[40]$} \\
\hline$k_{3}$ & Battery coefficient from lithium metal process & $\%$ & 22 & 2015 & {$[40]$} \\
\hline $\mathbf{B u}$ & Butyl lithium coefficient from lithium metal process & $\%$ & 56 & 2015 & {$[40]$} \\
\hline
\end{tabular}

Table A3. Data source of the annual production. Adapted from USGS mineral yearbooks [48].

\begin{tabular}{|c|c|c|c|c|c|c|c|c|c|c|c|c|c|c|c|}
\hline \multirow[b]{2}{*}{ Year } & \multicolumn{3}{|c|}{ Chile } & \multicolumn{3}{|c|}{ Argentina } & \multirow{2}{*}{\begin{tabular}{|c|}
$\begin{array}{c}\text { United } \\
\text { States }\end{array}$ \\
Brine \\
\end{tabular}} & \multirow{2}{*}{\begin{tabular}{|l|} 
Australia \\
Spodumene
\end{tabular}} & \multirow{2}{*}{$\begin{array}{c}\text { Brazil } \\
\text { Concentrate }\end{array}$} & \multirow{2}{*}{\begin{tabular}{|c|} 
Canada \\
Spodumene \\
\end{tabular}} & \multirow{2}{*}{$\begin{array}{c}\text { China } \\
\text { Carbonate }\end{array}$} & \multirow{2}{*}{\begin{tabular}{|l|} 
Namibia \\
$\begin{array}{l}\text { Chiefly } \\
\text { Petalite }\end{array}$
\end{tabular}} & \multirow{2}{*}{\begin{tabular}{|l} 
Portugal \\
Lepidolite
\end{tabular}} & \multirow{2}{*}{\begin{tabular}{|c|}
$\begin{array}{c}\text { Russia, } \\
\text { URSS }\end{array}$ \\
Minerals \\
Not \\
Specified \\
\end{tabular}} & \multirow{2}{*}{\begin{tabular}{|l|} 
Zimbabwe \\
Spodumene
\end{tabular}} \\
\hline & $\begin{array}{c}\text { Lithium } \\
\text { Carbonate, } \\
\text { Brine }\end{array}$ & $\begin{array}{l}\text { Lithium } \\
\text { Chloride }\end{array}$ & $\begin{array}{c}\text { Lithium } \\
\text { Hydroxide }\end{array}$ & $\begin{array}{c}\text { Spodumene } \\
\text { And } \\
\text { Amblygonite }\end{array}$ & \begin{tabular}{|c|} 
Lithium \\
Carbonate
\end{tabular} & $\begin{array}{l}\text { Lithium } \\
\text { Chloride }\end{array}$ & & & & & & & & & \\
\hline \begin{tabular}{|l|}
1981 \\
\end{tabular} & - & - & - & 28 & - & - & $\mathrm{w}$ & - & 2868 & - & - & 1392 & 990 & 60600 & 18126 \\
\hline 1982 & - & - & - & 125 & - & - & $\mathrm{w}$ & 90 & 3060 & - & - & 1146 & 998 & 60600 & 10788 \\
\hline 1983 & - & - & - & 168 & - & - & $\mathrm{w}$ & 1100 & 2339 & - & - & 860 & 601 & 60600 & 21657 \\
\hline \begin{tabular}{|l|}
1984 \\
\end{tabular} & 2326 & - & - & 24 & - & - & $\mathrm{w}$ & 7200 & 897 & 96 & - & 970 & 1086 & 60600 & 25270 \\
\hline 1985 & 4959 & - & - & 22 & - & - & $\mathrm{w}$ & 12300 & 963 & 330 & - & 2160 & 880 & 60600 & 30165 \\
\hline \begin{tabular}{|l|}
1986 \\
\end{tabular} & 4458 & - & - & 184 & - & - & $\mathrm{w}$ & 12703 & 2059 & 3500 & - & 835 & 1800 & 55000 & 32760 \\
\hline \begin{tabular}{|l|}
1987 \\
\end{tabular} & 6139 & - & - & 178 & - & - & $\mathrm{w}$ & 22279 & 2503 & 11500 & - & 1816 & 9380 & 55000 & 14959 \\
\hline \begin{tabular}{|l|}
1988 \\
\end{tabular} & 7332 & - & - & 119 & - & - & $\mathrm{w}$ & 30000 & 1471 & 14000 & - & 1642 & 14109 & 55000 & 15073 \\
\hline \begin{tabular}{|l|}
1989 \\
\end{tabular} & 7508 & - & - & 120 & - & - & $\mathrm{w}$ & 40000 & 1575 & 14000 & - & 1398 & 18264 & 55000 & 20647 \\
\hline \begin{tabular}{|l|}
1990 \\
\end{tabular} & 9080 & - & - & 69 & - & - & $\mathrm{w}$ & 40000 & 475 & 12000 & - & 1264 & 10600 & 55000 & 19100 \\
\hline \begin{tabular}{|l|}
1991 \\
\end{tabular} & 8580 & - & - & 287 & - & - & $\mathrm{w}$ & 40400 & 1560 & 12000 & - & 1190 & 10000 & 50000 & 9190 \\
\hline 1992 & 10823 & - & - & 620 & - & - & $\mathrm{w}$ & 42516 & 1600 & 18500 & - & 1162 & 15904 & 45000 & 12837 \\
\hline \begin{tabular}{|l|}
1993 \\
\end{tabular} & 10369 & - & - & 300 & - & - & $\mathrm{w}$ & 52900 & 1600 & 18900 & - & 742 & 13289 & 40000 & 18064 \\
\hline \begin{tabular}{|l|}
1994 \\
\end{tabular} & 10439 & - & - & 400 & - & - & $\mathrm{w}$ & 45987 & 1600 & 20000 & - & 1861 & 11352 & 2000 & 25279 \\
\hline 1995 & 12943 & - & - & 400 & - & - & $\mathrm{w}$ & 81841 & 1600 & 21000 & - & 2611 & 8740 & 2000 & 33498 \\
\hline \begin{tabular}{|l|}
1996 \\
\end{tabular} & 14180 & - & - & 400 & - & - & $\mathrm{w}$ & 117094 & 1600 & 22000 & - & 1972 & 7626 & 2000 & 30929 \\
\hline 1997 & 24246 & - & - & 697 & - & - & $\mathrm{w}$ & 88399 & 6948 & 22500 & - & 1019 & 6883 & 2000 & 49833 \\
\hline 1998 & 28377 & - & - & - & 6000 & 2500 & $\mathrm{w}$ & 63190 & 9485 & 22500 & - & 500 & 7000 & 2000 & 28055 \\
\hline 1999 & 30231 & - & - & - & 1592 & 2794 & $\mathrm{w}$ & 75824 & 11122 & 22500 & - & - & 14862 & 2000 & 36671 \\
\hline 2000 & 35869 & - & - & - & 2161 & 5182 & $\mathrm{w}$ & 65504 & 10875 & 22500 & - & - & 9352 & 2000 & 37914 \\
\hline 2001 & 31320 & - & - & - & - & 4512 & $\mathrm{w}$ & 79859 & 9084 & 22500 & - & - & 11571 & 2000 & 36103 \\
\hline 2002 & 35242 & - & - & - & 906 & 4729 & $\mathrm{w}$ & 79085 & 12046 & 22500 & - & - & 16325 & 2000 & 33172 \\
\hline 2003 & 41667 & - & - & - & 2850 & 4700 & $\mathrm{w}$ & 124410 & 9755 & 22500 & - & - & 24606 & 2000 & 12131 \\
\hline 2004 & 43971 & 494 & - & - & 4970 & 6303 & $\mathrm{w}$ & 118451 & 9084 & 22500 & - & - & 28696 & 2200 & 13710 \\
\hline 2005 & 43091 & 681 & 504 & - & 7288 & 8416 & $\mathrm{w}$ & 173635 & 8924 & 22500 & - & - & 26185 & 2200 & 37499 \\
\hline 2006 & 46241 & 1166 & 3794 & - & 8228 & 8336 & $\mathrm{w}$ & 222101 & 8585 & 22500 & - & - & 28497 & 2200 & 30000 \\
\hline 2007 & 51292 & 4185 & 4160 & - & 8863 & 8828 & $\mathrm{w}$ & 192277 & 7991 & 22500 & - & - & 34755 & - & 30000 \\
\hline 2008 & 48469 & 4362 & 4050 & - & 9984 & 7800 & $\mathrm{w}$ & 239528 & 14460 & 22000 & - & - & 34888 & - & 50000 \\
\hline 2009 & 25154 & 2397 & 2987 & - & 8450 & 4350 & $\mathrm{w}$ & 197482 & 15929 & 10000 & - & - & 37359 & - & 50000 \\
\hline 2010 & 44025 & 3725 & 5101 & - & 11196 & 6832 & $\mathrm{w}$ & 295000 & 15733 & 0 & 12000 & - & 40109 & - & 47000 \\
\hline 2011 & 59933 & 3864 & 5800 & - & 10000 & 4600 & $\mathrm{w}$ & 421396 & 7820 & 0 & 11300 & - & 37534 & - & 48000 \\
\hline 2012 & 62002 & 4145 & 5447 & - & 10535 & 4297 & $\mathrm{w}$ & 456921 & 7084 & 0 & 10000 & - & 20698 & - & 53000 \\
\hline 2013 & 52358 & 4091 & 4197 & - & 9248 & 5156 & $\mathrm{w}$ & 421000 & 7982 & 0 & 11200 & - & 19940 & - & 42000 \\
\hline 2014 & 55074 & 2985 & 4194 & - & 11698 & 7370 & $\mathrm{w}$ & 425000 & 8519 & 0 & 10100 & - & 17459 & - & 45000 \\
\hline 2015 & 50418 & 2069 & 3888 & - & 14137 & 5848 & $\mathrm{w}$ & 490000 & 8500 & 0 & 10700 & - & 17120 & - & 50000 \\
\hline 2016 & 67300 & 1600 & 6000 & - & 25500 & 6000 & $\mathrm{w}$ & 560000 & 8500 & 0 & 12200 & - & 25800 & - & 50000 \\
\hline
\end{tabular}

\section{REFERENCES}

[1] M. Frenzel, J. Kullik, M.A. Reuter, and J. Gutzmer, "Raw material "criticality'-sense or nonsense?", J. Phys. D Appl. Phys., vol. 50, no. $12,2017.123002$ [http://dx.doi.org/10.1088/1361-6463/aa5b64]

[2] Y. Jin, J. Kim, and B. Guillaume, "Review of critical material studies", Resour. Conserv. Recycling, vol. 113, pp. 77-87, 2016.

[http://dx.doi.org/10.1016/j.resconrec.2016.06.003]

[3] A. de Koning, R. Kleijn, G. Huppes, B. Sprecher, G. van Engelen, and 
A. Tukker, "Metal supply constraints for a low-carbon economy?", Resour. Conserv. Recycling, vol. 129, pp. 202-208, 2018.

[http://dx.doi.org/10.1016/j.resconrec.2017.10.040]

[4] G. Martin, L. Rentsch, M. Hoeck, and M. Bertau, "Lithium market research--global supply, future demand and price development", Energy Storage Mater., vol. 6, pp. 171-179, 2017.

[http://dx.doi.org/10.1016/j.ensm.2016.11.004]

[5] X. Sun, H. Hao, F. Zhao, and Z. Liu, Global Lithium Flow 1994 2015 : Implications for Improving Resource E ffi ciency and Security, 2018.

[6] H.U. Sverdrup, "Modelling global extraction, supply, price and depletion of the extractable geological resources with the LITHIUM model", Resour. Conserv. Recycling, vol. 114, pp. 112-129, 2016. [http://dx.doi.org/10.1016/j.resconrec.2016.07.002]

[7] International Energy Agency, Global EV Outlook 2017, 2017.

[8] O. Egbue, and S. Long, "Critical issues in the supply chain of lithium for electric vehicle batteries", Eng. Manag. J., vol. 24, no. 3, pp. 52-62, 2012.

[http://dx.doi.org/10.1080/10429247.2012.11431947]

[9] S. Ziemann, M. Weil, and L. Schebek, "Tracing the fate of lithium---The development of a material flow model", Resour. Conserv. Recycling, vol. 63, pp. 26-34, 2012.

[http://dx.doi.org/10.1016/j.resconrec.2012.04.002]

[10] H. Hao, Z. Liu, F. Zhao, Y. Geng, and J. Sarkis, "Material flow analysis of lithium in China", Resour. Policy, vol. 51, pp. 100-106, 2017.

[http://dx.doi.org/10.1016/j.resourpol.2016.12.005]

[11] X. Sun, H. Hao, F. Zhao, and Z. Liu, "Global Lithium Flow 1994-2015: Implications for Improving Resource Efficiency and Security", Environ. Sci. Technol., vol. 52, no. 5, pp. 2827-2834, 2018. [http://dx.doi.org/10.1021/acs.est.7b06092] [PMID: 29406757]

[12] T. Brown, A. Walters, N. Idoine, G. Gunn, R. A Shaw, and D. Rayner, Lithium, 2016.

[13] R. Spencer, and L. Hill, Specialty Minerals and Metals, 2016.

[14] W. Lv, Z. Wang, H. Cao, Y. Sun, Y. Zhang, and Z. Sun, "A critical review and analysis on the recycling of spent lithium-ion batteries", ACS Sustain. Chem.\& Eng., vol. 6, no. 2, pp. 1504-1521, 2018.

[http://dx.doi.org/10.1021/acssuschemeng.7b03811]

[15] A. Pehlken, S. Albach, and T. Vogt, "Is there a resource constraint related to lithium ion batteries in cars?", Int. J. Life Cycle Assess., vol. 22, no. 1, pp. 40-53, 2017.

[http://dx.doi.org/10.1007/s11367-015-0925-4]

[16] T. Brown, "Measurement of mineral supply diversity and its importance in assessing risk and criticality", Resour. Policy, vol. 58, no. May, pp. 202-218, 2018.

[http://dx.doi.org/10.1016/j.resourpol.2018.05.007]

[17] R. B. Wallace, "Lithium, A Strategic Element for Energy in the World Market",

[18] J.A. Ober, "Lithium, Minerals Yearbook-1994", US Geol. Surv. US $\begin{array}{lll}\text { Geol. Surv. (USGS), 1994. [electronic Resour } & \end{array}$ https//minerals.usgs.gov/minerals/pubs/commodity/lithium/

[19] J.A. Ober, "Lithium, Minerals Yearbook-2003", US Geol. Surv. US Geol. Surv. (USGS), 20032003. [electronic Resour https//minerals.usgs.gov/minerals/pubs/commodity/lithium/

[20] J.A. Ober, "Lithium, Minerals Yearbook-2004", US Geol. Surv. US Geol. Surv. (USGS), 2004. [electronic Resour. https//minerals.usgs.gov/minerals/pubs/commodity/lithium/

[21] J.A. Ober, "Lithium, Minerals Yearbook-2005", US Geol. Surv. US $\begin{array}{lll}\text { Geol. Surv. (USGS), 2005. [electronic Resour. } & \end{array}$ https//minerals.usgs.gov/minerals/pubs/commodity/lithium/

[22] J.A. Ober, Lithium, Minerals Yearbook-2006, 2006.US Geol. Surv. US $\begin{array}{lll}\text { Geol. Surv. (USGS), 2006. [electronic Resour. } & \end{array}$ https//minerals.usgs.gov/minerals/pubs/commodity/lithium/

[23] B.W. Jaskula, Lithium, Minerals Yearbook-2007., US Geol. Surv, 2010, pp. 41-44.

[24] B.W. Jaskula, Lithium, Minerals Yearbook-2008., US Geol. Surv,
2010, pp. 41-44.

[25] B.W. Jaskula, Lithium, Minerals Yearbook-2009., US Geol. Surv, 2011, pp. 41-44.

[26] B.W. Jaskula, Lithium, Minerals Yearbook-2010., US Geol. Surv, 2012, pp. 41-44.

[27] B.W. Jaskula, Lithium, Minerals Yearbook-2011., US Geol. Surv, 2013, pp. 41-44.

[28] B.W. Jaskula, Lithium, Minerals Yearbook-2012., US Geol. Surv, 2016, pp. 41-44.

[29] J.A. Ober, Lithium, Minerals Yearbook-1995, 1995.US Geol. Surv. US Geol. Surv. (USGS), 1995. [electronic Resour. https//minerals.usgs.gov/minerals/pubs/commodity/lithium/

[30] B.W. Jaskula, Lithium, Minerals Yearbook-2013., US Geol. Surv, 2015, pp. 41-44.

[31] B.W. Jaskula, Lithium, Minerals Yearbook-2014., US Geol. Surv, 2016, pp. 41-44.

[32] B.W. Jaskula, Lithium, Minerals Yearbook-2015., US Geol. Surv, 2017, pp. 41-44.

[33] J.A. Ober, "Lithium, Minerals Yearbook-1996", US Geol. Surv. US Geol. Surv. (USGS), 1996. [electronic Resour. https//minerals.usgs.gov/minerals/pubs/commodity/lithium/

[34] J.A. Ober, "Lithium, Minerals Yearbook-1997", US Geol. Surv. US Geol. Surv. (USGS), 1997. [electronic Resour. https//minerals.usgs.gov/minerals/pubs/commodity/lithium/

[35] J.A. Ober, "Lithium, Minerals Yearbook-1998", US Geol. Surv. US Geol. Surv. (USGS), 1998. [electronic Resour. https//minerals.usgs.gov/minerals/pubs/commodity/lithium/

[36] J.A. Ober, "Lithium, Minerals Yearbook-1999", US Geol. Surv. US Geol. Surv. (USGS), 1999. [electronic Resour. https//minerals.usgs.gov/minerals/pubs/commodity/lithium/

[37] J.A. Ober, "Lithium, Minerals Yearbook-2000", US Geol. Surv. US Geol. Surv. (USGS), 2000. [electronic Resour. https//minerals.usgs.gov/minerals/pubs/commodity/lithium/

[38] J.A. Ober, "Lithium, Minerals Yearbook-2001", US Geol. Surv. US Geol. Surv. (USGS), 2001. [electronic Resour. https//minerals.usgs.gov/minerals/pubs/commodity/lithium/

[39] J.A. Ober, Lithium, Minerals Yearbook-2002, 2002."US Geol. Surv. US Geol. Surv. (USGS)", [electronic Resour. https//minerals.usgs.gov/minerals/pubs/commodity/lithium/

[40] M. M. Foss, G. Gülen, C.-H. Tsai, D. Quijano, and B. Elliott, Battery Materials Value Chains.

[41] M. Hocking, J. Kan, P. Young, C. Terry, and D. Begleiter, "Lithium $101 "$,

[42] S. Glöser, M. Soulier, L. T. Espinoza, and M. Faulstich, "Using Dynamic Stock \& Flow Models for Global and Regional Material and Substance Flow Analysis in the Field of Industrial Ecology: The Example of a Global Copper Flow Model", no. July

[43] J.W. Forrester, "Industrial dynamics", J. Oper. Res. Soc., vol. 48, no. 10, pp. 1037-1041, 1997.

[http://dx.doi.org/10.1057/palgrave.jors.2600946]

[44] D. Chung, E. Elgqvist, D. Chung, and E. Elgqvist, "Automotive Lithium-ion Cell Manufacturing : Regional Cost Structures and Supply Chain Considerations Automotive Lithium-ion Cell Manufacturing: Regional Cost Structures and Supply Chain Considerations",

[45] S.K. Sharma, and G.K. Sharma, "Demand Forecasting Techniques visà-vis Demand Forecast for Lead", Procedia Earth Planet. Sci., vol. 11, pp. 418-424, 2015.

[http://dx.doi.org/10.1016/j.proeps.2015.06.041]

[46] R. Verma, M. M. Foss, G. Gülen, C.-H. Tsai, D. Quijano, and B. Elliott, "Battery Materials Value Chains",

[47] J. A. Ober, "Mineral commodity summaries 2018", [http://dx.doi.org/10.3133/70194932]

[48] B. Jaskula, "USGS science for a changing world", Lithium Statistics and Information.. [Online]. Available: https://www.usgs.gov/centers/ nmic/lithium-statistics-and-information 